\title{
AHP ve TOPSIS Yöntemleri Kullanılarak Motorlu Kurye Seçimi: İlaç Sektöründe Bir Uygulama
}

\author{
Derya Öztürk ${ }^{a}$, Murat Kemal Keleş ${ }^{\mathrm{b}}$,
}

\section{Özet}

İlaçların ecza depolarından eczanelere zamanında, hızlı ve güvenilir bir şekilde teslim edilmesi her iki taraf için de önemlidir. Bu çalışmanın amacı, ilaç sektöründe faaliyet gösteren bir ecza deposu için en uygun motorlu kurye seçimi probleminde AHP ve TOPSIS yöntemlerini kullanmaktır. Karar verici olarak firmanın personel seçiminden sorumlu uzman görüşüne başvurulmuştur. Literatür taraması ve firmanın personel müdürü ile yapılan görüşmeler sonucunda; "teknik yeterlilik", "fiziksel yeterlilik", "sosyal yeterlilik", "mesleki yeterlilik" ve "kişisel özellikler" olmak üzere beş ana kriter belirlenmiş ve bunların alt kriterleri tanımlanmıştır. AHP yöntemi ile ana ve alt kriterlerin ağırlıkları belirlenmiştir. Motorlu kurye adayları AHP ve TOPSIS yöntemleri kullanılarak ayrı ayrı sıralanmıştır. Analiz sonucunda, motorlu kurye seçim kriterleri arasından en önemli kriterin "teknik yeterlilik" kriteri, en önemsiz kriterin ise "sosyal yeterlilik" kriteri olduğu görülmüştür ve "Kurye 3" her iki yönteme göre yapılan sıralamada da en uygun aday olarak tespit edilmiştir.
Anahtar Kelimeler

Analitik Hiyerarşi Prosesi

TOPSIS

Personel seçimi

İlaç sektörü

Makale Hakkında

Geliş Tarihi: 12.01.2020

Kabul Tarihi: 10.06 .2020

Doi: $10.18026 /$ cbayarsos.673712

\section{Motorized Courier Selection Using AHP and TOPSIS Methods: An Application in Pharmaceutical Sector}

\begin{abstract}
Timely, fast and reliable delivery of medicines from pharmaceutical warehouse to pharmacies is important for both parties. The aim of this study is to use AHP and TOPSIS methods to select the most suitable motorized courier for a pharmaceutical warehouse operating in the pharmaceutical sector. As a decision maker a specialist opinion was consulted who was responsible for the firm's personnel selection. Literature review and as a result of interviews conducted with the firm's personnel manager were defined five main criteria (technical competence, physical competence, social competence, professional competence and personal characteristics) and subcriteria. Weights of the main and subcriteria were determined using the AHP method. Motorized courier candidates were ranked separately using AHP and TOPSIS methods. Analysis results showed that the most and least important criteria for motorized courier selection were technical competence and social competence, respectively and "Courier 3 " is the most suitable candidate according to both methods.
\end{abstract}

Keywords

Analytic Hierarchy Process

TOPSIS

Personnel selection

Pharmaceutical sector

About Article

Received: 12.01 .2020

Accepted: 10.06 .2020

Doi: $10.18026 /$ cbayarsos.673712

\footnotetext{
a Doç. Dr., Ordu Üniversitesi, Ünye İktisadi ve İdari Bilimler Fakültesi, İşletme Bölümü, E-mail: deryaozturk@odu.edu.tr, Orcid: 0000-0001-5287-6600. b muratkeles@isparta.edu.tr (Sorumlu yazar)

c Dr., Isparta Uygulamalı Bilimler Üniversitesi, Keçiborlu Meslek Yüksekokulu, Tasarım Bölümü, Keçiborlu / Isparta, E-mail: muratkeles@isparta.edu.tr, Orcid: 0000-0003-0374-6839.
} 


\section{Giriş}

İşletmeler, kaliteli ürünler üretmek, müşteri memnuniyetini sağlamak, maliyetleri düşürmek ve kâr sağlamak gibi bir takım amaçlar doğrultusunda faaliyet göstermektedirler. İşletmeler aynı zamanda faaliyet gösterdikleri sektörde yoğun rekabet ortamında ayakta kalabilmek ve rakiplerine karşı üstünlük sağlayabilmek için mücadele etmektedirler. İşletmelerin amaçlarına ulaşabilmesi ve rekabet üstü olabilmelerinin en önemli parametrelerinden biri de doğru ve kalifiye insan kaynağını seçmektir.

Üretim faktörlerinden biri olan emeğin kaynağı olarak insan faktörü doğru seçilirse işletmenin başarısında büyük katkı sağlayacaktır. Kalifiye, nitelikli personel seçimi hangi sektörde olursa olsun her işletme için oldukça önemlidir. İlaç sektöründe faaliyet gösteren işletmelerde de farklı pozisyonlarda personeller çalışmaktadır ve her personelin işletmeye görevleri icabı farklı katkıları bulunmaktadır. İlaç sektöründe ecza depolarında çalışan motorlu kurye personelleri de bu sektörde çalışan personel gruplarından biridir. Ecza depoları, çok sayıda ilaç firmasının ürünlerini faaliyet gösterdikleri yerlerdeki eczanelere, eczanelerden gelen talepler doğrultusunda motorlu kurye personelleri aracılığıyla ulaştırmaktadır. İlaç firmaları, ecza depoları sayesinde ürünlerini eczanelere ve dolayısıyla müşterilere teslim etmektedir. Eczaneden istenen ilaçların zamanında, hızlı ve güvenilir şekilde teslim edilmesi hem ecza deposu açısından hem de eczane açısından önemlidir. Bu çalışmanın amacı, yukarıda bahsedilen önemli görevi ifa eden motorlu kurye personellerinin işe alımında aranan kriterleri ve önem derecelerini tespit etmek ve konuyla ilgili bir uygulama yapmaktır.

Çalışmada öncelikle, AHP (Analitik Hiyerarşi Prosesi) ve TOPSIS (Technique for Order Preference by Similarity to Ideal Solution) yöntemlerinin kullanıldığı personel seçimi probleminin ele alındığı uygulamalardan örneklerin verildiği literatür araştırmasına yer verilmiştir. Daha sonra çalışmada kullanılan çok kriterli karar verme yöntemlerinden AHP ve TOPSIS'in metodolojisi anlatılmıştır. Uygulama kısmında ise, ilaç dağıtım sektöründe Samsun'da faaliyet gösteren bir ecza deposu firması için insan kaynakları birimine başvuran dört motorlu kurye adayının değerlendirmesi yapılmıştır. Değerlendirmede, çok kriterli karar verme (ÇKKV) yöntemlerinden AHP ve TOPSIS yöntemleri kullanılmıştır. AHP yöntemiyle, motorlu kurye seçiminde kullanılan kriterlerin önem derecesi tespit edilmiştir. Ecza deposunun istemiş olduğu en uygun motorlu kuryenin seçimi hem AHP yöntemiyle hem de TOPSIS yöntemiyle yapılmıştır. Son bölümde, analiz sonuçları değerlendirilmiş ve önerilerde bulunulmuştur.

\section{Literatür Taraması}

Efe ve Kurt (2018) yaptıkları çalışmada, bulanık genişletilmiş AHP ve bulanık TOPSIS yöntemlerini, bir liman işletmesi için en uygun insan kaynakları uzmanının seçilmesi problemine uygulamışlardır. Personel seçimi için sekiz kriter ile on adayı değerlendirmişlerdir. Liman işletmesinin insan kaynakları uzmanında aradığı en önemli kriterlerin "kendine güven" ve "plânlama ve organizasyon yeteneği” olduğu görülmüştür.

Tepe ve Görener (2014), kurumsal bir şirketin personel seçiminde AHP ve MOORA yöntemlerini kullanmışlardır. Üç ana kriter ve bu kriterlere bağlı dokuz alt kriter baz alınarak beş aday değerlendirilmiştir. Kriter ağırlıkları AHP yöntemiyle bulunmuş, adaylar MOORA yöntemiyle sıralanmıştır. 
Ilgaz (2018) yapmış olduğu çalışmada, bir lojistik şirketi için seçilecek operasyon elemanının değerlendirmesinde AHP ve TOPSIS yöntemlerini kullanmıştır. Dört ana kriter ve bu kriterlere bağlı on üç alt kriterin ağırlığı AHP yöntemiyle bulunmuş, işe başvuran beş aday TOPSIS yöntemiyle sıralanmıştır.

Koyuncu ve Özcan'ın (2014) çalışmalarında, otomotiv sektöründe faaliyet gösteren bir firmaya son bir yıl içinde alınmış altı mühendisin özellikleri AHP ve TOPSIS yöntemleri ile ayrı ayrı değerlendirilmiş ve her iki yönteme göre adaylar sıralanmıştır. Elde edilen sıralama sonuçları bu çalışanların performans puanlarıyla karşılaştırılmıştır. En az sapma AHP yönteminde görülmüştür.

Ilgaz Yıldırım ve Güzel (2019), turist rehberlerinin işe alım süreçlerinde önemli olan kriterlerin belirlenmesi ve bu kriterlerin ağırlıklarının tespit edilmesinde AHP yöntemini kullanmışlardır. Çalışma sonucunda turist rehberi işe alımında göz önünde bulundurulan altı kriter elde edilmiş ve AHP analizi sonrası bu kriterler arasında önem düzeyi en yüksek olan kriterin mesleki yeterlilik kriteri olduğu belirlenmiştir.

Tarcan İçigen ve İpekçi Çetin (2018), Antalya'da faaliyet gösteren beş yıldızlı bir otel için önbüro müdürü seçimi probleminde AHP ve TOPSIS yöntemlerini kullanmışlardır. Altı ana kriter ve bu ana kriterlere bağlı on beş alt kriterin ağırlı̆̆ 1 AHP yöntemiyle bulunmuş, on adayın sıralaması da TOPSIS yöntemiyle yapılmıştır. Analiz sonucunda, önbüro müdürü seçiminde en önemli kriterin "yabancı dil bilgisi" olduğu görülmüştür.

Taş, Bedir, Eren, Alağaş ve Çetin (2018) çalışmalarında, AHP ve TOPSIS yöntemlerini kullanarak Ankara'daki beş hastanenin kalp ve damar cerrahisi polikliniklerinin değerlendirmesini yapmışlardır. Hastane değerlendirilmesinde; hastane hekim bilgisi, temizlik ve fiziki koşullar, genel hastane bilgisi ve hastane imajı olmak üzere dört kriter baz alınmıştır. Kriterlerin ağırlıkları AHP yöntemi ile bulunmuş ve beş hastane, TOPSIS yöntemi ile sıralanmıştır. Kriterler içerisinde hastane hekim bilgisinin en önemli kriter olduğu görülmüştür.

Sezen Akar ve Çakır (2016) bulanık AHP ve MOORA yöntemlerini kullanarak lojistik sektöründe personel seçimi uygulaması yapmışlardır. Çalışmada, lojistik firmasına başvuran beş aday beş kriter üzerinden değerlendirilmiş ve bütünleşik çok kriterli karar verme yöntemi kullanılarak personel seçimi süreci tamamlanmıştır. Bu çalışmada personel seçimi sürecinde kullanılan bütünleşik yöntemin farklı sektörlere ve farklı seçim problemlerine uygulanabilirliği vurgulanmış, yöntemin kolay uygulanabilir olması, daha fazla kriter ve alternatif olması durumunda zaman tasarrufu bakımından avantaj sağladığı belirtilmiştir.

Yıldız ve Aksoy (2015) personel seçimi probleminde AHP yönteminden yararlanmışlardır. Otomotiv yan sanayisinde faaliyet gösteren bir işletmenin çeşitli bölümleri için alınması düşünülen beş personel AHP yöntemi ile değerlendirilmiştir. AHP yönteminin personel seçiminde karar vermede faydalı bir yöntem olduğunu belirtmişlerdir.

Hota, Sharma, ve Pavani (2014) yaptıkları çalışmada öğretmen seçiminde bulanık AHP ve bulanık TOPSIS yöntemlerini kullanmışlardır. Beş adet değerlendirme kriterinin ağırlıklarını bulanık AHP ile bulmuşlar, on öğretmen adayını da bulanık TOPSIS yöntemi ile sıralamışlardır.

Özbek ve Erol (2016), yaptıkları çalışmada AHP ve VIKOR yöntemlerini kullanarak tekstil sektöründe faaliyet gösteren bir işletmede personel seçimi yapmışlardır. Belirlenen sekiz 
kriterin ağırlığ1 AHP yöntemiyle bulunmuş, en önemli kriterin "tecrübe" kriteri olduğu tespit edilmiştir. Beş personel, hem AHP hem de VIKOR yöntemiyle sıralanmıştır. Her iki yöntemin sıralama sonucu da aynı çıkmıştır.

Karakış (2019) yapmış olduğu çalışmada, özel okullarda öğretmen seçimi problemine bulanık AHP ve bulanık TOPSIS ile çözüm getirmeye çalışmıştır. Dört ana kriter ve bu kriterlere bağlı on yedi alt kriterin ağırlığı bulanık AHP ile bulunmuş, beş aday öğretmen ise bulanık TOPSIS ile sıralanmıştır.

Kelemenis ve Askounis (2010) yaptıkları çalışmada, bilişim teknolojileri sektöründeki çok uluslu bir firmaya CEO seçiminde bulanık TOPSIS yöntemini kullanmışlardır. Dört aday, on bir kriter ile değerlendirilmiştir.

Gibney ve Shang (2007) yapmış oldukları çalışmada AHP yöntemini üniversitede dekan seçiminde kullanmışlardır. Çalışmada, iki ana kriter ve bunlara bağlı on yedi alt kriterle beş dekan adayı değerlendirilmiştir.

Safari, Cruz-Machado, Sarraf ve Maleki (2014) çalışmalarında TOPSIS ve Macar atama algoritması kullanarak doğru personel seçimi ile ilgili bir çözüm önermişlerdir. Çalışmada dört departman yöneticisiyle nominal grup tekniği yapılarak beş adet karar kriteri elde edilmiştir. Dört aday için belirlenen kriterler baz alınarak TOPSIS yöntemiyle veriler analiz edilmiştir.

Tüzemen ve Özdağoğlu (2007), Dokuz Eylül Üniversitesi Sosyal Bilimler Enstitüsü İşletme Doktora programı öğrencilerinin eş seçim kriterlerinin ağırlıklarını AHP yöntemiyle belirlemişlerdir. Çalışmada üç adet ana kriter ve bu kriterlere bağlı on bir alt kriter değerlendirilmiştir.

Abalı, Kutlu ve Eren (2012) çalışmalarında, Kırıkkale Üniversitesi Mühendislik Fakültesinde okuyan öğrencilerden burs veya yardım alacak öğrencilerin sıralanmasında AHP ve TOPSIS yöntemlerini kullanmışlardır. Çalışmada beş adet kriterin ağırlığı AHP ile belirlenmiş, beş öğrenci de TOPSIS yöntemi ile sıralanmıştır.

Sonuç olarak, literatürde personel seçimi konusunda yapılmış çalışmalar incelendiğinde ilaç sektöründe motorlu kurye seçim probleminin AHP-TOPSIS yöntemlerinin bütünleşik şekilde kullanıldığı ve iki yöntemin karşılaştırmalı olarak çözümüne ilişkin herhangi bir çalışmaya rastlanılmamıştır.

\section{Yöntem}

\section{Analitik Hiyerarşi Prosesi (AHP)}

AHP, 1970'lerde Saaty tarafından geliştirilmiş, çok sayıda kriter içeren karmaşık problemlerin çözümünde kullanılan bir karar verme yöntemidir. AHP yapı olarak, karar vericilerin karmaşık problemleri, problemin ana hedefi, kriterleri alt kriterler ve alternatifleri arasındaki ilişkiyi hiyerarşik olarak modellemelerine imkân tanır. AHP sayesinde karar vericiler, bilgilerini, deneyimlerini, önsezilerini mantıksal bir şekilde birleştirmek suretiyle hem objektif hem de sübjektif düşüncelerini karar sürecine dâhil edebilmektedirler (Kuruüzüm ve Atsan, 2001). Herhangi bir karar verme probleminde, karar vermede etkili olan değerlendirme kriterlerinin ağırlığı ve alternatiflerin sıralanması kişiden kişiye farklılık gösterebilmektedir. $\mathrm{Bu}$ tür problemlerin çözümünde AHP yöntemi çözüm imkânı sağlamaktadır (Yeşilyurt, Karakuş, Gür ve Eren, 2019). 
AHP'nin işlem adımları aşağıdaki gibidir (Soner ve Önüt, 2006):

Adım 1: Öncelikle ikili karşılaştırma matrisi oluşturulur. İkili karşılaştırma Saaty tarafından geliştirilen Çizelge 1'deki ikili karşılaştırma ölçeğine göre yapılır:

Çizelge 1. İkili Karşılaştırmalar Ölçeği (Saaty, 1990)

\begin{tabular}{ll}
\hline Önem Değerleri & Değer Tanımları \\
\hline 1 & İki kriter de eşit derece öneme sahiptir \\
3 & Bir kriter diğerine göre biraz önemlidir. \\
5 & Bir kriter diğerine göre güçlü şekilde önemlidir. \\
7 & Bir kriter diğerine göre çok güçlü şekilde önemlidir. \\
9 & Bir kriter diğerine göre çok büyük oranda önemlidir. \\
$2,4,6,8$ & İki önem derecesi arasında tercih yapılamıorsa \\
\hline
\end{tabular}

Adım 2: Elde edilen karşılaştırma matrisinin sütun toplamları alınıp, her değer kendi sütun toplamına bölünerek normalize matris elde edilir.

Adım 3: Satır ortalaması alınarak ağırlıklar elde edilir.

Adım 4: Elde edilen ağırlıkların kullanılabilmesi için karşılaştırma matrisinin tutarlı olması gerekmektedir. Bu yüzden karşılaştırma matrisinin tutarlılığına bakılır.

A. $w=\lambda_{\max } . w$

eşitliğini sağlayan $\lambda_{\max }$ vektörü elde edilmelidir. Formüldeki, “ $A$ ” karşılaştırma matrisi, “ $w$ ” ise elde edilen ağırlık matrisidir.

Daha sonra, $\lambda_{\max }$ kullanılarak tutarlılığa yakınlık göstergesi olarak ifade edilen "tutarlılık indeksi $(C I)^{\prime \prime}$ hesaplanir.

$C I=\frac{\lambda_{\max }-n}{n-1}$

Tutarlılık oranının elde edilebilmesi için Rassallık indeksinden $(R I)$ yararlanılır. Bu değer farklı matris boyutları için farklı değerler almaktadır. Farklı matris boyutları için $R I$ değerleri Çizelge.2' de gösterilmiştir:

Çizelge 2. Rassallık İndeksi

\begin{tabular}{cccccccccccccccc}
\hline $\mathrm{n}$ & 1 & 2 & 3 & 4 & 5 & 6 & 7 & 8 & 9 & 10 & 11 & 12 & 13 & 14 & 15 \\
Değer & 0 & 0 & 0,58 & 0,9 & 1,12 & 1,24 & 1,32 & 1,41 & 1,45 & 1,49 & 1,51 & 1,53 & 1,56 & 1,57 & 1,59 \\
\hline
\end{tabular}

Kaynak: Saaty, 1980

Tutarlılık oranı $(C R), C I^{\prime}$ nın, $R I^{\prime}$ ya oranlanmasıyla elde edilir. Saaty'e (1980) göre tutarlılık oranı $0,1^{\prime}$ den küçükse karşılaştırma matrisi tutarlıdır.

$C R=\frac{C I}{R I}$

Eğer, karar verme probleminde kriter ağırlıklarının bulunmasına ek olarak alternatiflerin de sıralaması AHP ile yapılacaksa sürece son bir adım daha eklenir.

$\mathrm{Bu}$ aşamada her bir alternatifin ayrı ayrı öncelik değerini bulabilmek için, her bir kriterin ağırlık değeri ile alternatiflerin kriterlere göre önemlerinin çarpımlarının toplamı alınır (Asoğlu ve Eren, 2018). 


\section{TOPSIS Yöntemi}

Hwang \& Yoon tarafından 1981 yılında geliştirilen TOPSIS yöntemi, çok kriterli bir karar verme tekniğidir. Yöntemin temeli "pozitif ideal çözüm"e en yakın mesafedeki ve "negatif ideal çözüm"e en uzak mesafedeki alternatifi seçmeye dayanmaktadır. Altı aşamadan oluşan TOPSIS yönteminin adımları aşağıda tanımlanmıştır (Dumanoğlu ve Ergül, 2010; Mahmoodzadeh, Shahrabi, Pariazar ve Zaeri, 2007; Asoğlu ve Eren, 2018);

1. Adım: Karar Matrisinin (A) Oluşturulması: “ $A$ ” matrisi uzman kişiler aracıllı̆ıyla oluşturulan karar (başlangıç) matrisidir. Karar matrisinin satır bölümünde üstünlükleri göstermek amaçlı alternatifler, sütun bölümünde ise karar verme aşamasında kullanılacak değerlendirme faktörleri (kriterler) yer almaktadır. Karar matrisi örneği aşağıdaki gibidir:

$A_{i j}=\left[\begin{array}{cccc}x_{11} & x_{12} & \ldots & x_{1 n} \\ x_{21} & x_{22} & \ldots & x_{2 n} \\ \ldots & \ldots & \ldots & \ldots \\ x_{m 1} & x_{m 2} & \ldots & x_{m n}\end{array}\right]$

$A_{i j}$ matrisinde " $m$ " karar noktası sayısını, " $n$ " ise değerlendirme faktörü sayısını nitelemektedir.

2. Adım: Normalize Edilmiş Karar Matrisinin $(R)$ Oluşturulması: Normalize edilmiş karar matrisi, $A$ matrisinin elemanlarından yararlanarak oluşturulur. Aşağıdaki formül yardımıyla elde edilir:

$$
r_{i j}=\frac{a_{i j}}{\sqrt{\sum_{k=1}^{m} a_{k j}^{2}}}
$$

$R$ matrisi aşağıdaki şekilde oluşur:

$R_{i j}=\left[\begin{array}{cccc}r_{11} & r_{12} & \ldots & r_{1 n} \\ r_{21} & r_{22} & \ldots & r_{2 n} \\ \ldots & \ldots & \ldots & \ldots \\ r_{m 1} & r_{m 2} & \ldots & r_{m n}\end{array}\right]$

$(i=1,2,3, \ldots, m ; j=1,2,3, \ldots, n)$

3.Adım: Ağırlıklı Normalize Edilmiş Karar Matrisinin (V) Oluşturulması: Bu aşamada değerlendirme faktörlerine ilişkin ağırlık değerleri $\left(w_{i}\right)$ belirlenir. Faktörlerin ağırlık değerleri toplamı 1 olmalıdır $\left(\sum_{i=1}^{n} w_{i}=1\right)$. Daha sonra normalize edilmiş karar matrisinin $(R)$ her bir sütunundaki elemanlar ilgili ağırlık değeri $\left(w_{i}\right)$ değeri ile çarpılarak ağırlıklı normalize edilmiş karar matrisi $(V)$ oluşturulur. Ağırlıklı normalize edilmiş karar matrisi $(V)$, aşağıda gösterilmiştir:

$V_{i j}=\left[\begin{array}{cccc}w_{1} r_{11} & w_{2} r_{12} & \ldots & w_{n} r_{1 n} \\ w_{1} r_{21} & w_{2} r_{22} & \ldots & w_{n} r_{2 n} \\ \ldots & \ldots & \ldots & \ldots \\ w_{1} r_{m 1} & w_{2} r_{m 2} & \ldots & w_{n} r_{m n}\end{array}\right]$

4. Adım: Pozitif $\left(A^{*}\right)$ ve Negatif İdeal $\left(A^{-}\right)$Çözümlerin Oluşturulması: Pozitif çözüm setinin oluşturulabilmesi için, $(V)$ matrisinin sütün değerlerinin yani ağırlıklandırılmış değerlendirme 
faktörlerinin ilgili değerlendirme faktörü maksimizasyon yönlü ise en büyüğü, minimizasyon yönlü ise en küçüğü seçilir.

Pozitif çözüm seti aşağıda (1)'de belirtilen formül ile bulunmaktadır.

$$
A^{*}=\left\{\left(\max _{i} v_{i j} \mid j \in J\right),\left(\min _{i} v_{i j} \mid j \in J^{\prime}\right\}\right.
$$

(8) formülü yardımıla $A^{*}=\left\{v_{1}^{*}, v_{2}^{*}, \ldots, v_{n}^{*}\right\}$ şeklinde bir set elde edilir.

Negatif ideal çözüm seti, $(V)$ matrisindeki ağırlıklandırılmış değerlendirme faktörlerinin yani sütun değerlerinin en küçükleri (ilgili değerlendirme faktörü maksimizasyon yönlü ise en büyüğü) seçilerek bulunur. Negatif ideal çözüm seti aşağıdaki formül ile bulunur.

$$
A^{-}=\left\{\left(\min _{i} v_{i j} \mid j \in J\right),\left(\max _{i} v_{i j} \mid j \in J^{\prime}\right\}\right.
$$

(9) formülü yardımıyla $A^{-}=\left\{v_{1}^{-}, v_{2}^{-}, \ldots, v_{n}^{-}\right\}$şeklinde bir set elde edilir. Her iki formülde de $J$ fayda (maksimizasyon), $J^{\prime}$ ise kayıp (minimizasyon) değerini göstermektedir. Gerek pozitif gerekse negatif ideal çözüm seti, değerlendirme faktörü sayısı yani " $m$ " elemandan oluşmaktadır.

5. Adım: Ayırım Ölçülerinin Hesaplanması: TOPSIS yönteminde her bir alternatife ilişkin değerlendirme faktör değerinin pozitif ve negatif ideal çözüm setinden sapmaları euclidian uzaklık yaklaşımından yararlanılarak hesaplanmaktadır. Buradan elde edilen alternatiflere ilişkin sapma değerleri ise pozitif ayırım $\left(S_{i}^{*}\right)$ ve negatif ideal ayırım $\left(S_{i}^{-}\right)$ölçüsü olarak adlandırılmaktadır. Pozitif ayırım $\left(S_{i}^{*}\right)$ ölçüsünün hesaplanması (10) nolu formülde, negatif ideal ayırım ( $S_{i}^{-}$) ölçüsünün hesaplanması ise (11) nolu formülde gösterilmiştir.

$$
\begin{aligned}
& S_{i}^{*}=\sqrt{\sum_{j=1}^{n}\left(v_{i j}-v_{j}^{*}\right)^{2}} \\
& S_{i}^{-}=\sqrt{\sum_{j=1}^{n}\left(v_{i j}-v_{j}^{-}\right)^{2}}
\end{aligned}
$$

6. Adım: İdeal Çözüme Göreli Yakınlığın Hesaplanması: Her bir karar noktasının ideal çözüme göreli yakınlığının $\left(C_{i}^{*}\right)$ hesaplanması, 5 . adımda hesaplanan pozitif ve negatif ideal ayırım ölçülerinden yararlanılarak yapılır. Hesaplamada kullanılan ölçüt negatif ideal ayırım ölçüsünün toplam ayırım ölçüsü içindeki payı kadardır. İdeal çözüme göreli yakınlık değeri (12) nolu formüldeki hesaplama ile bulunur.

$$
C_{i}^{*}=\frac{S_{i}^{-}}{S_{i}^{-}+S_{i}^{*}}
$$

Burada $C_{i}^{*}$ değeri $0 \leq C_{i}^{*} \leq 1$ aralığında değer alır ve $C_{i}^{*}=1$ ilgili alternatifin ideal çözüme, $C_{i}^{*}=0$ ilgili alternatifin negatif ideal çözüme mutlak yakınlığını göstermektedir. Bu adımda elde edilen değerlerin büyüklük sırasına göre dizilmesi suretiyle alternatiflerin önem sıraları belirlenmiş olur. 


\section{Bulgular}

Uygulama, Samsun ili İlkadım ilçesinde 1995 yılından itibaren ilaç dağıtım sektöründe faaliyet gösteren büyük ölçekli bir ecza deposu firmasında gerçekleştirilmiştir. Çalışma kapsamında, eczanelerin ihtiyaçlarına daha kısa sürede cevap verebilmek amacıyla ilaç sevkiyatında bulunan dört motorlu kurye adayı değerlendirmeye tabi tutulmuştur. İlk olarak firmanın personel işlerinden sorumlu müdürüne, literatürde kurye seçiminde yararlanılan kriterler hakkında bilgi verilmiştir. Bilgilendirme sonrası personel müdürü, kurye seçiminde önem verdiği kriterleri ve bu kriterlere bağlı alt kriterleri belirlemiştir. Daha sonra personel müdürüne ana kriterler, alt kriterler ve alternatiflerin değerlendirilmesinde kullanılan ölçekler hakkında bilgiler verilmiş, motorlu kurye seçimi için hazırlanmış anket formunu doldurması istenmiştir. Araştırma verilerinin elde edilmesinde yüz yüze anket yöntemi uygulanmıştır. Elde edilen verilerin analizinde Excel programı kullanılmıştır.

\section{AHP Yönteminin Uygulanması}

Hiyerarşik yapının oluşturulabilmesi için ilk olarak çalışmanın amacının belirlenmesi gerekmektedir. Amaç belirlendikten sonra, belirlenen amaca uygun kriterler ve bunlara ait alt kriterler belirlenmektedir. Karar hiyerarşisinin en alt noktasında ise karar alternatifleri yer almaktadır. Şekil 1'de gösterilen hiyerarşik yapının amacı, ilaç sektöründe faaliyet gösteren bir ecza deposunun için en uygun motorlu kurye seçimi problemini çözmektir. Bu amaca uygun olarak kriter ve alternatifler de hiyerarşik yapıda görülmektedir.

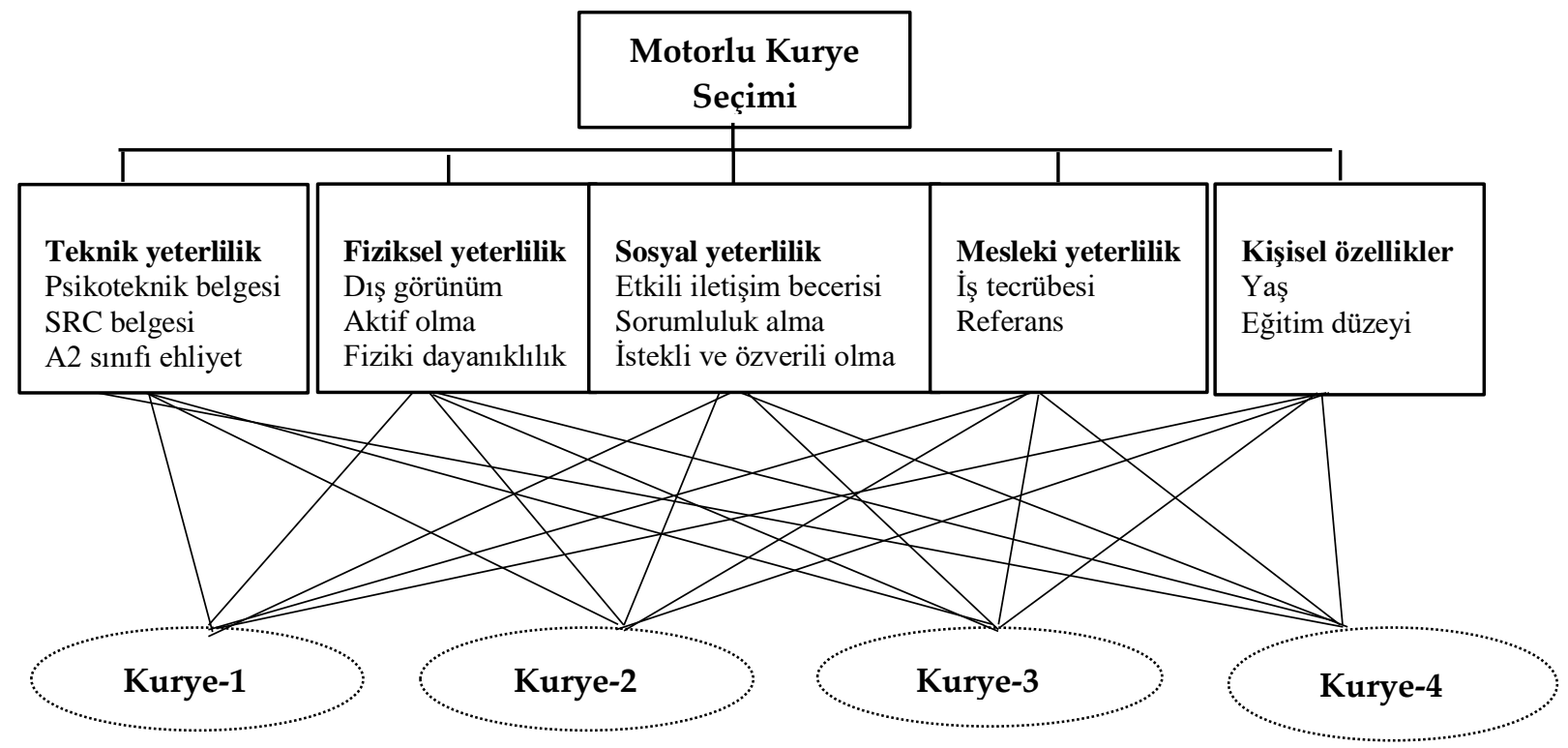

Şekil 1. Problemin Hiyerarşik Yapısı

Ana kriterler sırasıyla; "teknik yeterlilik", "fiziksel yeterlilik", "sosyal yeterlilik", "mesleki yeterlilik" ve "kişisel özellikler" şeklindedir. Motorlu kurye seçimini etkileyen özelliklerden, psikoteknik belgesi (PB), SRC belgesi (SRCB) ve A2 sinıfı ehliyet (A2SE) "teknik yeterlilik" kriterini oluşturmaktadır. Dış görünüm (DG), aktif olma (AO) ve fiziki dayanıklılık (FD) "fiziksel yeterlilik" kriterini; etkili iletişim becerisi (EIB), sorumluluk alma (SA), istekli ve özverili olma (IVÖO) "sosyal yeterlilik" kriterini; iş tecrübesi (IT) ve referans (R) "mesleki yeterlilik" kriterini; yaş (Y) ve eğitim düzeyi (ED) "kişisel özellikler" kriterini oluşturmaktadır. $\mathrm{Bu}$ aşamadan sonra $\mathrm{AHP}$ 'nin ikinci ve üçüncü adımında ikili karşılaştırma matrisleri oluşturulmuş, göreli öncelikler belirlenmiştir. Ayrıca tüm matrislerin tutarlılık oranları 1, 2, 3, nolu formüller yardımıyla hesaplanmıştır. Ana kriterlerin birbirleriyle karşılaştırılmaları 
sonucu "teknik yeterlilik" kriterinin diğer kriterlere göre daha önemli olduğu görülmüş̧tür $(0,576)$. Diğer kriterlerin önem sıralaması ise mesleki yeterlilik $(0,216)$, kişisel özellikler $(0,108)$, fiziksel yeterlilik $(0,062)$ ve sosyal yeterlilik $(0,038)$ şeklindedir. İkili karşılaştırma matrisinin tutarlılık oranı 0,06 olup, bu oran değerlendirmenin güvenilir olduğunun bir göstergesidir (Tablo 1).

Tablo 1. Ana Kriterlerin Karşılaştırılması

\begin{tabular}{lcccccc}
\hline & $\begin{array}{c}\text { Teknik } \\
\text { yeterlilik }\end{array}$ & $\begin{array}{c}\text { Fiziksel } \\
\text { yeterlilik }\end{array}$ & $\begin{array}{c}\text { Sosyal } \\
\text { yeterlilik }\end{array}$ & $\begin{array}{c}\text { Mesleki } \\
\text { yeterlilik }\end{array}$ & $\begin{array}{c}\text { Kişisel } \\
\text { özellikler }\end{array}$ & Göreli öncelik \\
\hline Teknik yeterlilik & 1,000 & 7,000 & 9,000 & 5,000 & 8,000 & 0,576 \\
Fiziksel yeterlilik & 0,143 & 1,000 & 2,000 & 0,167 & 0,500 & 0,062 \\
Sosyal yeterlilik & 0,111 & 0,500 & 1,000 & 0,167 & 0,250 & 0,038 \\
Mesleki yeterlilik & 0,200 & 6,000 & 6,000 & 1,000 & 2,000 & 0,216 \\
Kişisel özellikler & 0,125 & 2,000 & 4,000 & 0,500 & 1,000 & 0,108 \\
\hline
\end{tabular}

Tutarlılık Oranı: 0,063

Alt kriterlerin ikili karşılaştırmaları, göreli öncelikleri ve tutarlılık oranları Tablo 2-Tablo 6' da gösterilmiştir. Buna göre; teknik yeterlilik kriteri açısından A2 sınıfı ehliyet $(0,808)$, fiziksel yeterlilik kriteri açısından fiziki dayanıklılık $(0,539)$, sosyal yeterlilik kriteri açısından istekli ve özverili olma $(0,539)$, mesleki yeterlilik kriteri açısından iş tecrübesi $(0,750)$ ve kişisel özellikler kriteri açısından ise yaş $(0,667)$ en önemli alt kriterler olarak görülmektedir. Tüm matrislerin tutarlılık oranı 0,10'un altındadır.

Tablo 2. Teknik Yeterlilik Alt Kriterlerinin Karşılaştırılması

\begin{tabular}{lcccc}
\hline & Psikoteknik belgesi & SRC belgesi & A2 sınıfı ehliyet & Göreli öncelik \\
\hline Psikoteknik belgesi & 1,000 & 0,500 & 0,111 & 0,074 \\
SRC belgesi & 2,000 & 1,000 & 0,111 & 0,118 \\
A2 sinıfı ehliyet & 9,000 & 9,000 & 1,000 & 0,808 \\
\hline
\end{tabular}

Tutarlılık Oranı: 0,047

Tablo 3. Fiziksel Yeterlilik Alt Kriterlerinin Karşılaştırılması

\begin{tabular}{lcccc}
\hline & Diş görünüm & Aktif olma & Fiziki dayanıklılık & Göreli öncelik \\
\hline Dış görünüm & 1,000 & 0,333 & 0,500 & 0,164 \\
Aktif olma & 3,000 & 1,000 & 2,000 & 0,539 \\
Fiziki dayanıklılık & 2,000 & 0,500 & 1,000 & 0,297 \\
\hline
\end{tabular}

Tutarlılık Oranı: 0,008

Tablo 4. Sosyal Yeterlilik Alt Kriterlerinin Karşılaştırılması

\begin{tabular}{lcccc}
\hline & $\begin{array}{c}\text { Etkili iletişim } \\
\text { becerisi }\end{array}$ & $\begin{array}{c}\text { Sorumluluk } \\
\text { alma }\end{array}$ & $\begin{array}{c}\text { İstekli ve özverili } \\
\text { olma }\end{array}$ & $\begin{array}{c}\text { Göreli } \\
\text { öncelik }\end{array}$ \\
\hline Etkili iletişim becerisi & 1,000 & 0,500 & 0,333 & 0,164 \\
Sorumluluk alma & 2,000 & 1,000 & 0,500 & 0,297 \\
İstekli ve özverili olma & 3,000 & 2,000 & 1,000 & 0,539 \\
\hline Tutarllk Oran: 0,008 & & & &
\end{tabular}

Tutarlılık Oranı: 0,008

Tablo 5. Mesleki Yeterlilik Alt Kriterlerinin Karşılaştırılması

\begin{tabular}{lccc}
\hline & İş tecrübesi & Referans & Göreli öncelik \\
\hline İş tecrübesi & 1,000 & 3,000 & 0,750 \\
Referans & 0,333 & 1,000 & 0,250 \\
\hline
\end{tabular}


Tablo 6. Kişisel Özellikler Alt Kriterlerinin Karşılaştırılması

\begin{tabular}{lccc}
\hline & Yaş & Eğitim düzeyi & Göreli öncelik \\
\hline Yaş & 1,000 & 2,000 & 0,667 \\
Eğitim düzeyi & 0,500 & 1,000 & 0,333 \\
\hline
\end{tabular}

Alt kriterlerin ikili karşılaştırmalarından sonra, her bir alt kriter için alternatiflerin öncelik değerleri hesaplanmıştır (Tablo 7-Tablo 19).

Tablo 7. Psikoteknik Belgesi Açısından Alternatiflerin İkili Karşılaştırma Matrisi

\begin{tabular}{lccccc}
\hline Motorlu kuryeler & Kurye 1 & Kurye 2 & Kurye 3 & Kurye 4 & Göreli öncelik \\
\hline Kurye 1 & 1,000 & 1,000 & 1,000 & 1,000 & 0,250 \\
Kurye 2 & 1,000 & 1,000 & 1,000 & 1,000 & 0,250 \\
Kurye 3 & 1,000 & 1,000 & 1,000 & 1,000 & 0,250 \\
Kurye 4 & 1,000 & 1,000 & 1,000 & 1,000 & 0,250 \\
\hline
\end{tabular}

Tutarlılık Oranı: 0,000

Tablo 8. SRC Belgesi Açısından Alternatiflerin İkili Karşılaştırma Matrisi

\begin{tabular}{lccccc}
\hline Motorlu kuryeler & Kurye 1 & Kurye 2 & Kurye 3 & Kurye 4 & Göreli öncelik \\
\hline Kurye 1 & 1,000 & 1,000 & 1,000 & 1,000 & 0,250 \\
Kurye 2 & 1,000 & 1,000 & 1,000 & 1,000 & 0,250 \\
Kurye 3 & 1,000 & 1,000 & 1,000 & 1,000 & 0,250 \\
Kurye 4 & 1,000 & 1,000 & 1,000 & 1,000 & 0,250 \\
\hline
\end{tabular}

Tutarlılık Oranı: 0,000

Tablo 9. A2 Sınıfı Ehliyet Açısından Alternatiflerin İkili Karşılaştırma Matrisi

\begin{tabular}{lccccc}
\hline Motorlu kuryeler & Kurye 1 & Kurye 2 & Kurye 3 & Kurye 4 & Göreli öncelik \\
\hline Kurye 1 & 1,000 & 1,000 & 1,000 & 1,000 & 0,250 \\
Kurye 2 & 1,000 & 1,000 & 1,000 & 1,000 & 0,250 \\
Kurye 3 & 1,000 & 1,000 & 1,000 & 1,000 & 0,250 \\
Kurye 4 & 1,000 & 1,000 & 1,000 & 1,000 & 0,250 \\
\hline
\end{tabular}

Tutarlılık Oranı: 0,000

Tablo 10. Dış Görünüm Açısından Alternatiflerin İkili Karşılaştırma Matrisi

\begin{tabular}{lccccc}
\hline Motorlu kuryeler & Kurye 1 & Kurye 2 & Kurye 3 & Kurye 4 & Göreli öncelik \\
\hline Kurye 1 & 1,000 & 0,333 & 0,500 & 2,000 & 0,169 \\
Kurye 2 & 3,000 & 1,000 & 2,000 & 2,000 & 0,416 \\
Kurye 3 & 2,000 & 0,500 & 1,000 & 3,000 & 0,289 \\
Kurye 4 & 0,500 & 0,500 & 0,333 & 1,000 & 0,126 \\
\hline
\end{tabular}

Tutarlılık Oranı: 0,061

Tablo 11. Aktif Olma Açısından Alternatiflerin İkili Karşılaştırma Matrisi

\begin{tabular}{lccccc}
\hline Motorlu kuryeler & Kurye 1 & Kurye 2 & Kurye 3 & Kurye 4 & Göreli öncelik \\
\hline Kurye 1 & 1,000 & 0,500 & 2,000 & 3,000 & 0,283 \\
Kurye 2 & 2,000 & 1,000 & 2,000 & 4,000 & 0,426 \\
Kurye 3 & 0,500 & 0,500 & 1,000 & 3,000 & 0,203 \\
Kurye 4 & 0,333 & 0,250 & 0,333 & 1,000 & 0,088 \\
\hline
\end{tabular}

Tutarlılık Oranı: 0,030 
Tablo 12. Fiziki Dayanıklılık Açısından Alternatiflerin İkili Karşılaştırma Matrisi

\begin{tabular}{lccccc}
\hline Motorlu kuryeler & Kurye 1 & Kurye 2 & Kurye 3 & Kurye 4 & Göreli öncelik \\
\hline Kurye 1 & 1,000 & 1,000 & 3,000 & 4,000 & 0,379 \\
Kurye 2 & 1,000 & 1,000 & 3,000 & 5,000 & 0,400 \\
Kurye 3 & 0,333 & 0,333 & 1,000 & 2,000 & 0,140 \\
Kurye 4 & 0,250 & 0,200 & 0,500 & 1,000 & 0,081 \\
\hline Tutarlilik Orani: 0,006 & & & &
\end{tabular}

Tablo 13. Etkili İletişim Açısından Alternatiflerin İkili Karşılaştırma Matrisi

\begin{tabular}{lccccc}
\hline Motorlu kuryeler & Kurye 1 & Kurye 2 & Kurye 3 & Kurye 4 & Göreli öncelik \\
\hline Kurye 1 & 1,000 & 4,000 & 3,000 & 2,000 & 0,478 \\
Kurye 2 & 0,250 & 1,000 & 0,500 & 1,000 & 0,128 \\
Kurye 3 & 0,333 & 2,000 & 1,000 & 2,000 & 0,236 \\
Kurye 4 & 0,500 & 1,000 & 0,500 & 1,000 & 0,158 \\
\hline
\end{tabular}

Tutarlılık Oranı: 0,044

Tablo 14. Sorumluluk Alma Açısından Alternatiflerin İkili Karşılaştırma Matrisi

\begin{tabular}{lccccc}
\hline Motorlu kuryeler & Kurye 1 & Kurye 2 & Kurye 3 & Kurye 4 & Göreli öncelik \\
\hline Kurye 1 & 1,000 & 3,000 & 1,000 & 2,000 & 0,349 \\
Kurye 2 & 0,333 & 1,000 & 0,500 & 0,333 & 0,114 \\
Kurye 3 & 1,000 & 2,000 & 1,000 & 2,000 & 0,321 \\
Kurye 4 & 0,500 & 3,000 & 0,500 & 1,000 & 0,216 \\
\hline
\end{tabular}

Tutarlılık Oranı: 0,044

Tablo 15. İstekli ve Özverili Olma Açısından Alternatiflerin İkili Karşılaştırma Matrisi

\begin{tabular}{lccccc}
\hline Motorlu kuryeler & Kurye 1 & Kurye 2 & Kurye 3 & Kurye 4 & Göreli öncelik \\
\hline Kurye 1 & 1,000 & 2,000 & 2,000 & 4,000 & 0,444 \\
Kurye 2 & 0,500 & 1,000 & 0,500 & 1,000 & 0,160 \\
Kurye 3 & 0,500 & 2,000 & 1,000 & 2,000 & 0,264 \\
Kurye 4 & 0,250 & 1,000 & 0,500 & 1,000 & 0,132 \\
\hline
\end{tabular}

Tutarlılık Oranı: 0,022

Tablo 16. İş Tecrübesi Açısından Alternatiflerin İkili Karşılaştırma Matrisi

\begin{tabular}{lccccc}
\hline Motorlu kuryeler & Kurye 1 & Kurye 2 & Kurye 3 & Kurye 4 & Göreli öncelik \\
\hline Kurye 1 & 1,000 & 2,000 & 0,500 & 3,000 & 0,281 \\
Kurye 2 & 0,500 & 1,000 & 0,250 & 0,500 & 0,107 \\
Kurye 3 & 2,000 & 4,000 & 1,000 & 3,000 & 0,461 \\
Kurye 4 & 0,333 & 2,000 & 0,333 & 1,000 & 0,151 \\
\hline
\end{tabular}

Tutarlılık Oranı: 0,044

Tablo 17. Referans Açısından Alternatiflerin İkili Karşılaştırma Matrisi

\begin{tabular}{lccccc}
\hline Motorlu kuryeler & Kurye 1 & Kurye 2 & Kurye 3 & Kurye 4 & Göreli öncelik \\
\hline Kurye 1 & 1,000 & 3,000 & 0,500 & 1,000 & 0,250 \\
Kurye 2 & 0,333 & 1,000 & 0,333 & 0,500 & 0,111 \\
Kurye 3 & 2,000 & 3,000 & 1,000 & 2,000 & 0,417 \\
Kurye 4 & 1,000 & 2,000 & 0,500 & 1,000 & 0,222 \\
\hline
\end{tabular}

Tutarlılık Oranı: 0,017 
Tablo 18. Yaş Açısından Alternatiflerin İkili Karşılaştırma Matrisi

\begin{tabular}{lccccc}
\hline Motorlu kuryeler & Kurye 1 & Kurye 2 & Kurye 3 & Kurye 4 & Göreli öncelik \\
\hline Kurye 1 & 1,000 & 6,000 & 3,000 & 2,000 & 0,484 \\
Kurye 2 & 0,167 & 1,000 & 0,250 & 0,333 & 0,067 \\
Kurye 3 & 0,333 & 4,000 & 1,000 & 2,000 & 0,260 \\
Kurye 4 & 0,500 & 3,000 & 0,500 & 1,000 & 0,189 \\
\hline Tutarlılık Oranı: 0,044 & & & &
\end{tabular}

Tablo 19. Eğitim Düzeyi Açısından Alternatiflerin İkili Karşılaştırma Matrisi

\begin{tabular}{lccccc}
\hline Motorlu kuryeler & Kurye 1 & Kurye 2 & Kurye 3 & Kurye 4 & Göreli öncelik \\
\hline Kurye 1 & 1,000 & 5,000 & 2,000 & 1,000 & 0,393 \\
Kurye 2 & 0,200 & 1,000 & 0,333 & 0,500 & 0,096 \\
Kurye 3 & 0,500 & 3,000 & 1,000 & 1,000 & 0,244 \\
Kurye 4 & 1,000 & 2,000 & 1,000 & 1,000 & 0,267 \\
\hline
\end{tabular}

Tutarlılık Oranı: 0,036

Elde edilen alt kriterlerin ağırlık değerleri ile hiyerarşik yapıda bağlı oldukları kritere ilişkin ağırlık değeri çarpılarak her bir alt kriterin nihai ağırlık değeri $(W)$ hesaplanmıştır (Tablo 20).

Tablo 20. Kriter ve Alt Kriterlerin Ağırlıkları Matrisi

\begin{tabular}{|c|c|c|c|c|}
\hline Kriterler & Ağırlıklar & Alt-Kriterler & Ağırlıklar & $\mathbf{W}$ \\
\hline \multirow{3}{*}{ Teknik Yeterlilik } & \multirow{3}{*}{0,576} & Psikoteknik belgesi & 0,074 & 0,043 \\
\hline & & SRC belgesi & 0,118 & 0,068 \\
\hline & & A2 sinıfı motosiklet ehliyeti & 0,808 & 0,466 \\
\hline \multirow{3}{*}{ Fiziksel Yeterlilik } & \multirow{3}{*}{0,062} & Diş görünüm & 0,164 & 0,010 \\
\hline & & Aktif olma & 0,539 & 0,033 \\
\hline & & Fiziki dayanıklılık & 0,297 & 0,018 \\
\hline \multirow{3}{*}{ Sosyal Yeterlilik } & \multirow{3}{*}{0,038} & Etkili iletişim becerisi & 0,164 & 0,006 \\
\hline & & Sorumluluk alma & 0,297 & 0,011 \\
\hline & & İstekli ve özverili olma & 0,539 & 0,021 \\
\hline \multirow{2}{*}{ Mesleki Yeterlilik } & \multirow{2}{*}{0,216} & İş tecrübesi & 0,750 & 0,162 \\
\hline & & Referans & 0,250 & 0,054 \\
\hline \multirow{2}{*}{ Kişisel Özellikler } & \multirow{2}{*}{0,108} & Yaş & 0,667 & 0,072 \\
\hline & & Eğitim düzeyi & 0,333 & 0,036 \\
\hline
\end{tabular}

AHP'nin son adımında ise, her bir alt kriter için alternatiflerin öncelik değerleri hesaplandıktan sonra elde edilen matrisin elemanları, alt kriterlerin öncelik değerleri ile çarpılarak alternatiflerin genel öncelik değerleri elde edilmiştir (Tablo 21).

Tablo 21. Ana Kriterler ve Alt Kriterlere Göre Firma Öncelikleri

\begin{tabular}{|c|c|c|c|c|c|c|c|c|c|c|c|c|c|c|}
\hline & \multicolumn{3}{|c|}{$\begin{array}{c}\text { Teknik yeterlilik } \\
(0,576)\end{array}$} & \multicolumn{3}{|c|}{$\begin{array}{c}\text { Fiziksel yeterlilik } \\
(0,062)\end{array}$} & \multicolumn{3}{|c|}{$\begin{array}{c}\text { Sosyal yeterlilik } \\
(0,038)\end{array}$} & \multicolumn{2}{|c|}{$\begin{array}{c}\text { Mesleki yeterlilik } \\
(0,216)\end{array}$} & \multicolumn{2}{|c|}{$\begin{array}{c}\text { Kişisel özellikler } \\
(0,108)\end{array}$} & \multirow{2}{*}{ G.Ö } \\
\hline & $\begin{array}{c}\text { PB } \\
(0,043)\end{array}$ & & $\begin{array}{c}\text { A2SE } \\
(0,466)\end{array}$ & DG & $\begin{array}{c}\mathrm{AO} \\
(0,033)\end{array}$ & $\begin{array}{c}\text { FD } \\
(0,018)\end{array}$ & $\begin{array}{c}\text { EIB } \\
(0,006)\end{array}$ & $\begin{array}{c}\text { SA } \\
(0,011)\end{array}$ & $\begin{array}{l}\text { İVÖO } \\
(0,021)\end{array}$ & $\begin{array}{c}\text { İT } \\
(0,162)\end{array}$ & $\begin{array}{c}\mathrm{R} \\
(0,054)\end{array}$ & $\begin{array}{c}\mathrm{Y} \\
(0,072)\end{array}$ & $\begin{array}{c}\text { ED } \\
(0,036)\end{array}$ & \\
\hline & & 0250 & & & & 0,379 & 0,478 & & 0,444 & & & & 0,393 & 0,286 \\
\hline & & & 0,250 & & & 0,400 & 0,128 & & 0,160 & & & 0,067 & 0,096 & 0,207 \\
\hline & 250 & 0,250 & 0,250 & 0,289 & 0,203 & 0,140 & 0,236 & 0,321 & 0,264 & 0,461 & 0,417 & 0,260 & 0,244 & 0,292 \\
\hline Kurye 4 & 0,250 & 0,250 & 0,250 & 0,126 & 0,088 & 0,081 & 0,158 & 0,216 & 0,132 & 0,151 & 0,222 & 0,189 & 0,267 & 0,215 \\
\hline
\end{tabular}




\section{TOPSIS yönteminin uygulanması}

Altı adımda gerçekleştirilen TOPSIS yönteminin ilk adımında karar matrisi elde edilmiştir. Karar matrisi, karar vericinin kuryelere daha önceden belirlenen kriterlere göre 1-10 arasında vermiş olduğu puanlardan oluşmaktadır (Tablo 22).

Tablo 22. Karar Matrisi

\begin{tabular}{|c|c|c|c|c|c|c|c|c|c|c|c|c|c|}
\hline & PB & SRCB & A2SE & DG & $\mathrm{AO}$ & FD & EİB & SA & İVÖO & İT & $\mathbf{R}$ & $Y$ & ED \\
\hline Kurye 1 & 7,000 & 8,000 & 10,000 & 6,000 & 7,000 & 7,000 & 8,000 & 8,000 & 8,000 & 7,000 & 7,000 & 8,000 & 8,000 \\
\hline Kurye 2 & 7,000 & 8,000 & 10,000 & 10,000 & 10,000 & 10,000 & 5,000 & 5,000 & 6,000 & 5,000 & 5,000 & 5,000 & 5,000 \\
\hline Kurye 3 & 7,000 & 8,000 & 10,000 & 7,000 & 6,000 & 6,000 & 7,000 & 7,000 & 7,000 & 8,000 & 8,000 & 7,000 & 6,000 \\
\hline Kurye 4 & 7,000 & 8,000 & 10,000 & 5,000 & 5,000 & 5,000 & 6,000 & 6,000 & 5,000 & 6,000 & 6,000 & 6,000 & 7,000 \\
\hline
\end{tabular}

İkinci adımda ise karar matrisi 5 nolu denklem kullanılarak normalize edilmiştir. Karar matrisinin normalleştirilme işlemi; sütunlardaki her bir değerin, ilgili sütundaki bütün değerlerin kareleri toplamının kareköküne bölünüp tek paydaya indirgenmesiyle bulunmuştur (Tablo 23).

Tablo 23. Normalize Edilmiş Karar Matrisi

\begin{tabular}{|c|c|c|c|c|c|c|c|c|c|c|c|c|c|}
\hline & PB & SRCB & A2SE & DG & AO & FD & EIB & SA & İVÖO & İT & $\mathbf{R}$ & $\mathbf{Y}$ & ED \\
\hline Kury & 0,500 & 0,500 & 0,500 & 0,414 & 0,483 & 0,483 & 0,606 & 0,606 & 0,606 & 0,531 & 0,531 & 0,606 & 0,606 \\
\hline urye 2 & 0,500 & 0,500 & 500 & 0,690 & 0,690 & 0,690 & 0,379 & 0,379 & 0,455 & 0,379 & 0,379 & 0,379 & 0,379 \\
\hline Kurye 3 & 0,500 & 0,500 & 0,500 & 0,483 & 0,414 & 0,414 & 0,531 & 0,531 & 0,531 & 0,606 & 0,606 & 0,531 & 0,455 \\
\hline Kurye 4 & 0,500 & 0,500 & 0,500 & 0,345 & 0,345 & 0,345 & 0,455 & 0,455 & 0,379 & 0,455 & 0,455 & 0,455 & 0,531 \\
\hline
\end{tabular}

Üçüncü adımda 7 nolu denklemde görüldüğü şekilde ağırlıklandırılmış karar matrisi elde edilmiştir. Bunun için de bir önceki aşamada oluşturulan normalize edilmiş karar matrisi değerleri AHP'de elde edilen kriterlerin ağırlık katsayıları $(W)$ (Tablo 24) ile çarpılmış ve Tablo 25 'de sunulmuştur.

Tablo 24. Kriter Ağırlık Değerleri

\begin{tabular}{rrllrrrrrrrrrr}
\hline & PB & SRCB & A2SE & DG & AO & FD & ĖंB & SA & IVÖO & İT & R & Y & ED \\
\hline $\mathrm{W}$ & 0,043 & 0,068 & 0,466 & 0,010 & 0,033 & 0,018 & 0,006 & 0,011 & 0,021 & 0,162 & 0,054 & 0,072 & 0,036 \\
\hline
\end{tabular}

Tablo 25. Ağırlıklandırılmış karar matrisi

\begin{tabular}{|c|c|c|c|c|c|c|c|c|c|c|c|c|c|}
\hline & PB & SRCB & A2SE & DG & AO & FD & EİB & SA & İVÖO & İT & $\mathbf{R}$ & $Y$ & ED \\
\hline Kurye 1 & 0,021 & 0,034 & 0,233 & 0,004 & 0,016 & 0,009 & 0,004 & 0,007 & 0,013 & 0,086 & 0,029 & 0,044 & 0,022 \\
\hline Kurye 2 & 0,021 & 0,034 & 0,233 & 0,007 & 0,023 & 0,012 & 0,002 & 0,004 & 0,009 & 0,061 & 0,020 & 0,027 & 0,014 \\
\hline Kurye 3 & 0,021 & 0,034 & 0,233 & 0,005 & 0,014 & 0,007 & 0,003 & 0,006 & 0,011 & 0,098 & 0,033 & 0,038 & 0,016 \\
\hline Kurye 4 & 0,021 & 0,034 & 0,233 & 0,003 & 0,011 & 0,006 & 0,003 & 0,005 & 0,008 & 0,074 & 0,025 & 0,033 & 0,019 \\
\hline
\end{tabular}

Dördüncü adım pozitif (8 nolu denklem) ve negatif ideal çözümlerin (9 nolu denklem) belirlendiği aşamadır. Ağırlıklı karar matrisinde her kriterin ilgili sütunundan ideal çözüm için pozitif ideal ve negatif ideal çözüm için negatif ideal değerler seçilerek, pozitif ideal ve negatif ideal çözüm değerleri belirlenir. TOPSIS yönteminin mantığı, pozitif ideal çözüme en yakın alternatiflerin seçilmesi ve böylece çözümün fayda kriterlerini maksimize ederken maliyet kriterlerini de minimize etmesidir (Benitez, Martin ve Roman, 2007). En iyi alternatif ise pozitif ideal çözüme en yakın, negatif ideal çözüme en uzak olan alternatiftir (Wang ve Elhag, 2006). Pozitif ideal çözüm seti oluşturulurken firma için Y kriteri açısından motorlu kurye adaylarının 18 yaşını doldurmuş ve mümkünse 30 yaşından genç olması tercih sebebi 
olduğundan Y sütunundaki en küçük değer seçilmiştir. Diğer kriterler için sütunlardaki en büyük değerler $A^{*}$ vektörünün ilgili elemanlarıdır. Negatif ideal çözüm seti ise $Y$ kriteri açısından yaşı en büyük olan motorlu kurye adaylarından oluşacağından Y sütunundaki en büyük değer seçilmiştir. Diğer kriterler için sütunlardaki en küçük değerler $\mathrm{A}^{-}$vektörünün ilgili elemanlarıdır (Tablo 26).

Tablo 26. Pozitif ve Negatif İdeal Çözüm Setleri

\begin{tabular}{|c|c|c|c|c|c|c|c|c|c|c|c|c|c|}
\hline & PB & SRCB & A2SE & DG & AO & FD & EİB & SA & İVÖO & İT & $\mathbf{R}$ & Y & ED \\
\hline $\mathrm{A}^{*}$ & 021 & 0,034 & 0,233 & 007 & 0,023 & 0,013 & 0,004 & 0,007 & 0,013 & 0,098 & 0,033 & 0,027 & 0,022 \\
\hline $\mathrm{A}^{-}$ & 0,021 & 0,034 & 0,233 & 0,003 & 0,011 & 0,006 & 0,002 & 0,004 & 0,008 & 0,061 & 0,020 & 0,044 & 0,014 \\
\hline
\end{tabular}

Beşinci adımda pozitif ve negatif ideal çözüm setlerinde yer alan değerler kullanılarak her bir alternatif için hesaplanan pozitif (10 nolu denklem) ve negatif ayrım değerleri (11 nolu denklem) hesaplanmış, Tablo 27 - Tablo 28' de verilmiştir.

Tablo 27. Pozitif İdeal Çözüme Uzaklık Değerleri

\begin{tabular}{ccccccccc}
\hline & PB & SRCB & A2SE & DG & AO & FD & EİB & SA \\
\hline Kurye 1 & 0,00000000 & 0,00000000 & 0,00000000 & 0,00000780 & 0,00004752 & 0,00001446 & 0,00000000 & 0,00000000 \\
Kurye 2 & 0,00000000 & 0,00000000 & 0,00000000 & 0,00000000 & 0,00000000 & 0,00000000 & 0,00000204 & 0,00000673 \\
Kurye 3 & 0,00000000 & 0,00000000 & 0,00000000 & 0,00000438 & 0,00008449 & 0,00002570 & 0,00000023 & 0,00000075 \\
Kurye 4 & 0,00000000 & 0,00000000 & 0,00000000 & 0,00001219 & 0,00013202 & 0,00004016 & 0,00000091 & 0,00000299 \\
\hline
\end{tabular}

Tablo 27'nin devam1

\begin{tabular}{ccccccccc}
\hline & IVÖO & İT & R & Y & ED & TOPLAM & KAREKÖKÜ & S $^{*}$ \\
\hline Kurye 1 & 0,00000000 & 0,00015071 & 0,00001675 & 0,00026861 & 0,00000000 & 0,00050585 & 0,02249110 & S1 \\
Kurye 2 & 0,00000983 & 0,00135640 & 0,00015071 & 0,00000000 & 0,00006715 & 0,00159286 & 0,03991059 & S2 \\
Kurye 3 & 0,00000246 & 0,00000000 & 0,00000000 & 0,00011938 & 0,00002985 & 0,00026724 & 0,01634739 & S3 \\
Kurye 4 & 0,00002211 & 0,00060284 & 0,00006698 & 0,00002985 & 0,00000746 & 0,00091750 & 0,03029030 & S4 \\
\hline
\end{tabular}

Tablo 28. Negatif İdeal Çözüme Uzaklık Değerleri

\begin{tabular}{ccccccccc}
\hline & PB & SRCB & A2SE & DG & AO & FD & EİB & SA \\
\hline Kurye 1 & 0,00000000 & 0,00000000 & 0,00000000 & 0,00000049 & 0,00002112 & 0,00000643 & 0,00000204 & 0,00000673 \\
Kurye 2 & 0,00000000 & 0,00000000 & 0,00000000 & 0,00001219 & 0,00013202 & 0,00004016 & 0,00000000 & 0,00000000 \\
Kurye 3 & 0,00000000 & 0,00000000 & 0,00000000 & 0,00000195 & 0,00000528 & 0,00000161 & 0,00000091 & 0,00000299 \\
Kurye 4 & 0,00000000 & 0,00000000 & 0,00000000 & 0,00000000 & 0,00000000 & 0,00000000 & 0,00000023 & 0,00000075 \\
\hline
\end{tabular}

Tablo $28^{\prime}$ in devam1

\begin{tabular}{lcccccccc}
\hline & IVÖO & İT & R & Y & ED & TOPLAM & KAREKÖKÜ & S- \\
\hline Kurye 1 & 0,00002211 & 0,00060284 & 0,00006698 & 0,00000000 & 0,00006715 & 0,00079589 & 0,02821149 & S1 \\
Kurye 2 & 0,00000246 & 0,00000000 & 0,00000000 & 0,00026861 & 0,00000000 & 0,00045543 & 0,02134079 & S2 \\
Kurye 3 & 0,00000983 & 0,00135640 & 0,00015071 & 0,00002985 & 0,00000746 & 0,00156698 & 0,03958505 & S3 \\
Kurye 4 & 0,00000000 & 0,00015071 & 0,00001675 & 0,00011938 & 0,00002985 & 0,00031766 & 0,01782295 & S4 \\
\hline
\end{tabular}

Son adımda ise 12 nolu denklem kullanılarak ideal çözüme göre yakınlığın hesaplanması yapılmıştır. İdeal çözüme göre yakınlık değerleri; her bir alternatif değeri için negatif ideal çözüm değerini, kendi değeri ve aynı alternatifin pozitif ideal çözüm değerinin toplamına bölünmesiyle bulunmuştur (Tablo 29). 
Tablo 29. İdeal Çözüme Göre Yakınlık

\begin{tabular}{ll}
\hline $\mathrm{C}^{*}$ & \\
\hline $\mathrm{C}^{*}{ }_{1}$ & 0,556 \\
$\mathrm{C}^{*}{ }_{2}$ & 0,348 \\
$\mathrm{C}^{*}{ }_{3}$ & 0,708 \\
$\mathrm{C}^{*}{ }_{4}$ & 0,370 \\
\hline
\end{tabular}

\section{AHP ve TOPSIS Yöntemlerinin Sonuçlarının Karşılaştırılması}

İlaç sektöründe faaliyet gösteren ecza deposu için motorlu kurye adaylarının AHP ve TOPSIS yöntemlerine göre değerlendirilmesi sonucu elde edilen sıralama sonuçları Tablo 30'da verilmiştir. Her iki yönteme göre de motorlu kurye adaylarının sıralamasının aynı olduğu görülmekte ve sonuçlar birbirini desteklemektedir. Buna göre her iki yöntemde de oluşan siralama en iyiden en kötüye doğru; "Kurye 3", "Kurye 1", "Kurye 4" ve "Kurye 2" şeklindedir. Elde edilen sonuçlara göre, ecza deposunun en yüksek skora sahip olan "Kurye 3" ile çalışması uygun bulunmuştur.

Tablo 30. AHP ve TOPSIS Yöntemlerinin Karşılaştırma Tablosu

\begin{tabular}{lcccc}
\hline \multirow{2}{*}{ Alternatifler } & \multicolumn{2}{c}{ Öncelik Değerleri } & \multicolumn{2}{c}{ Siralama } \\
\cline { 2 - 5 } & AHP & TOPSIS & AHP & TOPSIS \\
\hline Kurye 1 & 0,286 & 0,556 & 2 & 2 \\
Kurye 2 & 0,207 & 0,348 & 4 & 4 \\
Kurye 3 & 0,292 & 0,708 & 1 & 1 \\
Kurye 4 & 0,215 & 0,370 & 3 & 3 \\
\hline
\end{tabular}

\section{Sonuç}

İlaç sektöründe faaliyet gösteren firmaların motorlu kurye seçimlerini doğru belirlemeleri sevkiyat süreçlerinde zaman, hız ve güvenilirlik açısından rekabet avantajı sağlayacaktır. Dolayısıyla ecza depoları için motorlu kurye seçim problemi son derece önemli hale gelmektedir. Bu çalışma ile, bir ecza deposu firmasının ilaç sevkiyatında kullandığı potansiyel motorlu kuryeleri, ÇKKV yöntemlerinden AHP ve TOPSIS yöntemleri ile değerlendirilmiştir. Firmanın uzman görüşüne dayanılarak motorlu kurye seçiminde kullanılan teknik yeterlilik, fiziksel yeterlilik, sosyal yeterlilik, mesleki yeterlilik ve kişisel özellikler olarak 5 ana kriter belirlenmiş ve bunların 13 alt kriteri tanımlanmıştır. Belirlenen ana ve alt kriterlere göre firmanın eczanelere ilaç sevkiyatında kullandığı dört motorlu kurye değerlendirilmiş ve öncelik siralamaları belirlenmiştir. AHP'de elde edilen sonuçlara göre motorlu kurye seçiminde en önemli ana kriter \%57,6 ile teknik yeterliliktir. Ecza depoları motorlu kurye alımlarında büyük bir titizlik göstermektedir. Motorlu kurye alımlarında adayların A2 ehliyetine sahip olması bir zorunluluktur. Bunun yanı sıra ilaç sektöründe sevkiyatların zamanında ve daha güvenli yapılabilmesi için adayların sürücü belgesinin yanında mesleki yeterlilik belgesi yani SRC belgesi ve psikoteknik raporuna sahip olmaları konusunda da hassasiyet gösterilmektedir. Çalışmada kullanılan diğer ana kriterlerin önem sıralaması ise $\% 21,6$ ile mesleki yeterlilik, \%10,8 ile kişisel özellikler, \%6,2 ile fiziksel yeterlilik ve \%3,8 ile sosyal yeterlilik kriteri şeklinde tespit edilmiştir. Mesleki yeterlilik kriterinin alt kriterleri kendi içerisinde karşılaştırıldığında \%75 ile iş tecrübesinin diğerlerine göre daha önemli olduğu tespit edilmiştir. Aynı şekilde kişisel özellikler kriterinde \%66,7 ile yaş, fiziksel 
yeterlilik kriterinde $\% 53,9$ ile aktif olma ve sosyal yeterlilik kriterinde ise $\% 53,9$ ile istekli ve özverili olma kriteri önemli bulunmuştur. Alternatiflerin üstünlük sıralamaları her iki yöntemde de aynı şekilde bulunmuştur. Ecza deposu firması için en uygun motorlu kurye adayı AHP yönteminde \%29,2'lik değeriyle “Kurye 3"tür. TOPSIS yöntemiyle yapılan hesaplamada da ilk sırada "Kurye 3" olduğu görülmüştür. Buna göre ecza deposu eczanelere ilaç sevkiyatında motorlu kurye tercihini “Kurye 3" yönünde kullanması uygundur.

Literatürde yer alan çalışmalar incelendiğinde ilaç sektöründe motorlu kurye seçimine yönelik herhangi bir çalışmaya rastlanılmamıştır. Bu nedenle çalışma orjinal nitelikte olup, çalışmanın literatüre önemli bir katkı sağlayacağı düşünülmektedir. Motorlu kurye seçiminde göz önünde bulundurulması gereken kriterlerin belirlenmiş olması da literatüre önemli bir katkı olarak belirtilebilir. Bundan sonra yapılacak çalışmalarda; eğer motorlu kurye personel seçimi uygulaması yapılacaksa, ÇKKV yöntemlerinden AHP ve TOPSIS harici farklı yöntemler tercih edilebilir. Ayrıca, ilaç sektörü haricinde farklı sektörler için kurye personeli seçimi uygulanabilir.

\section{Kaynakça}

Abalı, Y.A., Kutlu, B.S., \& Eren, T. (2012). Çok Ölçütlü Karar Verme Yöntemleri ile Bursiyer Seçimi: Bir Öğretim Kurumunda Uygulama. Atatürk Üniversitesi İktisadi ve İdari Bilimler Dergisi, 26 (3-4), 259-272.

Asoğlu, İ., \& Eren, T. (2018). AHS, TOPSIS, PROMETHEE Yöntemleri ile Bir İşletme için Kargo Şirketi Seçimi. Yalova Sosyal Bilimler Dergisi, 8(16), 102-122.

Benitez, J.M., Martin, J.C., \& Roman, C. (2007). Using Fuzzy Number for Measuring Quality of Service in the Hotel Industry. Tourism Management, 28(2), 544-555.

Dumanoğlu, S., \& N. Ergül (2010). İMKB'de İşlem Gören Teknoloji Şirketlerinin Mali Performans Ölçümü. Muhasebe ve Finansman Dergisi, 48, 101-111.

Efe, B., \& Kurt, M. (2018). Bir Liman İşletmesinde Personel Seçimi Uygulaması. Karaelmas Fen ve Mühendislik Dergisi, 8(2), 417-427.

Gibney, R., \& Shang, J. (2007). Decision Making İn Academia: A Case of the Dean Selection Process. Mathematical and Computer Modeling, 46 (7-8), 1030-1040.

Hota, H. S., Sharma, L. K., \& Pavani, S. (2014). Fuzzy TOPSIS method applied for ranking of teacher in higher education. In Intelligent Computing, Networking, and Informatics, vol 243. Springer, New Delhi, 1225-1232.

Ilgaz, A. (2018). Lojistik Sektöründe Personel Seçim Kriterlerinin AHP ve TOPSIS Yöntemleri İle Değerlendirilmesi. Süleyman Demirel Üniversitesi Sosyal Bilimler Enstitüsü Dergisi, 2018/3, 32, 586-605.

Ilgaz Yıldırım, B., \& Güzel, Ö. (2019). Seyahat Acentelerinin Turist Rehberi Seçim Kriterlerinin Analitik Hiyerarşi Süreci (AHS) Yöntemi ile Değerlendirilmesi. Anatolia: Turizm Araştırmaları Dergisi, 30 (1), 69-81.

Karakış, E. (2019). Bulanık AHP ve Bulanık TOPSIS ile Bütünleşik Karar Destek Modeli Önerisi: Özel Okullarda Öğretmen Seçimi. Erciyes Üniversitesi İktisadi ve İdari Bilimler Fakültesi Dergisi, Say1: 53, Haziran 2019, 112-137. 
Kelemenis, A., \& Askounis, D. (2010). A New TOPSIS-based Multi-criteria Approach to Personnel Selection. Expert Systems with Applications, 37 (7), 4999-5008.

Koyuncu, O., \& Özcan, M. (2014). Personel Seçim Sürecinde Analitik Hiyerarşi Süreci ve Topsis Yöntemlerinin Karşılaştırılması: Otomotiv Sektöründe Bir Uygulama. H.Ü. İktisadi ve İdari Bilimler Fakültesi Dergisi, 32 (2), 195-218.

Kuruüzüm, A., \& Atsan, N. (2001). Analitik Hiyerarşi Yöntemi ve İşletmecilik Alanındaki Uygulamaları. Akdeniz İ.̇.B.F. Dergisi, 1(1), 83-105.

Mahmoodzadeh S., Shahrabi, J., Pariazar, M. \& Zaeri, M. S. (2007). Project Selection by Using Fuzzy AHP and TOPSIS Technique. World Academy of Science, Engineering and Technology, 30, 333-338.

Özbek, A., \& Erol, E. (2016). Analitik Hiyerarşi Süreci ve VIKOR Yöntemleriyle İşgören Seçimi: Tekstil Sektöründe Bir Uygulama. Kırıkkale Üniversitesi Sosyal Bilimler Dergisi, 6 (1), 93-108.

Saaty, T. L. (1980). The Analytic Hierarchy Process. New York: McGraw-Hill.

Saaty, T.L. (1990). How to Make a Decision: The Analytic Hierarchy Process. European Journal of Operational Research, 48 (1), 9-26.

Safari, H., Cruz-Machado, V., Sarraf, A.Z., \& Maleki, M. (2014). Multidimensional Personnel Selection Through Combination of TOPSIS and Hungary Assignment Algorithm. Management and Production Engineering Review, 5(1), 42-50.

Sezen Akar, G., \& Çakır, E. (2016). Lojistik Sektöründe Bütünleştirilmiş Bulanık AHP-MOORA Yaklaşımı ile Personel Seçimi. Yönetim ve Ekonomi Araştırmaları Dergisi, 14 (2), 185-199.

Soner, S., \& Önüt, S. (2006). Çok Kriterli Tedarikçi Seçimi: Bir ELECTRE-AHP Uygulaması. Mühendislik ve Fen Bilimleri Dergisi, Sigma, 2006/4:110-120.

Tarcan İçigen, E., \& İpekçi Çetin, E. (2018). AHP Temelli TOPSIS Yöntemi İle Konaklama İşletmelerinde Personel Seçimi. Balkan Sosyal Bilimler Dergisi, 7 (13), 179-187.

Taş, C., Bedir, N., Eren, T., Alağaş, H., \& Çetin, S. (2018). AHP-TOPSIS Yöntemleri Entegrasyonu İle Poliklinik Değerlendirilmesi: Ankara'da Bir Uygulama. Sağglk Yönetimi Dergisi, 2 (1), 1-17.

Tepe, S., \& Görener, A. (2014). Analitik Hiyerarşi Süreci ve Moora Yöntemlerinin Personel Seçiminde Uygulanması. İstanbul Ticaret Üniversitesi Fen Bilimleri Dergisi, 13 (25), Bahar 2014, 1-14.

Tüzemen, A., \& Özdağoğlu, A. (2007). Doktora Öğrencilerinin Eş Seçiminde Önem Verdikleri Kriterlerin Analitik Hiyerarşi Süreci Yöntemi ile Belirlenmesi. Atatürk Üniversitesi İktisadi ve İdari Bilimler Dergisi, 21 (1) , 215-232.

Wang, Y.M., \& Elhag, T.M.S. (2006). Fuzzy TOPSIS Method Based On Alpha Level Sets With An Application To Bridge Risk Assessment. Expert Systems With Applications, 31, 309-319.

Yeşilyurt, B., Karakuş, K., Gür, Ş., \& Eren, T. (2019). Çok Ölçütlü Karar Verme Yöntemleri ile Hastane Bilgi Yönetim Sistemleri İçin Paket Programı Seçimi. Ticari Bilimler Fakültesi Dergisi, 3 (1), 1-21.

Yıldız M. S., \& Aksoy S. (2015) Analitik Hiyerarşi Prosesi İle Personel Seçimi Üzerine Bir Çalışma. Abant İzzet Baysal Üniversitesi Sosyal Bilimler Enstitüsü Dergisi, 15 (1), 59-83. 